\title{
Canopy Net Photosynthesis Rate of a Mongolian Oak (Quercus mongolica) Forest Estimated by Field Experimental Data
}

\author{
Seung Jin Joo, Soon-Ung Park* \\ Center for Atmospheric and Environmental Modeling, Seoul, Korea \\ Email: joo.seungjin@yahoo.co.kr, *supark@snu.ac.kr
}

How to cite this paper: Joo, S.J. and Park, S.-U. (2017) Canopy Net Photosynthesis Rate of a Mongolian Oak (Quercus mongolica) Forest Estimated by Field Experimental Data. American Journal of Plant Sciences, 8, 390-411.

https://doi.org/10.4236/ajps.2017.83027

Received: November 15, 2016

Accepted: February 3, 2017

Published: February 6, 2017

Copyright ( 92017 by authors and Scientific Research Publishing Inc. This work is licensed under the Creative Commons Attribution International License (CC BY 4.0).

http://creativecommons.org/licenses/by/4.0/

\begin{abstract}
The canopy net photosynthesis rate of Mongolian oak (Quercus mongolica) tree species that are dominant in East Asia and Korea is estimated with empirical models derived from field experimental data obtained from the NamSan site in Seoul, Korea for the growing period from early May to late October in 2010. The empirical models include the attenuation function of photosynthetic photon flux density (PPFD) $\left(r^{2}=0.98-0.99, p<0.001\right)$ and the photosynthetic light response function $\left(r^{2}=0.99, p<0.001\right)$ derived from the measured data at several levels within the canopy. The incident PPFD at each level within canopy significantly varies diurnally and seasonally due to the seasonal variation of the total plant area index $(\mathrm{TPAI}=$ leaf area index + wood silhouette area index) and the light shielding effect of light path-length through the canopy in association with the variation of solar elevation angle. Consequently, a remarkable seasonal variation of the total canopy net photosynthesis rate of $Q$. mongolica forest stand is found for its growing period. The PPFD exceeding $1000 \mu \mathrm{mol} \mathrm{m}{ }^{-2} \cdot \mathrm{s}^{-1}$ is found to cause the decrease of net photosynthesis rate due to the thermal stress in the early (May) and late (September) growing period. During the whole growing season, the estimated total canopy net photosynthesis rate is found to be about $3.3 \mathrm{~kg} \mathrm{CO}_{2} \mathrm{~m}^{-2}$.
\end{abstract}

\section{Keywords}

Mongolian Oak (Quercus mongolica), Canopy Net Photosynthesis Rate, PPFD, TPAI, Solar Elevation Angle

\section{Introduction}

A better understanding on the response of forest against current environmental factors is prerequisite for an accurate estimation of the potential global carbon 
cycle in association with future climate changes [1] [2] [3]. Therefore, much attention has been given to the subject of quantifying and identifying the carbon budget of forest ecosystems in the regional and global scales, whether the forest ecosystem is a sink or a source for atmospheric $\mathrm{CO}_{2}$ [4] [5].

The net carbon acquisition of forest ecosystem, as well as the net primary productivity (NPP) depends principally on the photosynthetic capacity and respiration of the ecosystem in the growing season of a given forest [6] [7]. The rate of instantaneous photosynthetic assimilation is one of the most important factors in determining the rate of $\mathrm{CO}_{2}$ exchange between the atmosphere and forest ecosystems [8] [9].

Many studies have been extensively focused on photosynthetic characteristics at the leaf level, including comparisons of different functional types, biochemistry and eco-physiology of plant species, and leaf morphologies [10] [11]. However, the structural distribution of plant's organs has rarely been studied even though it affects significantly the canopy photosynthesis rate at the stand level through the changes of the transmittance and interception patterns of the incident light within the canopy [12] [13].

The forest canopy photosynthesis depends upon its own eco-physiological and architectural properties [14], and meteorological factors such as light incidence, air temperature and humidity, atmospheric $\mathrm{CO}_{2}$ concentration and wind speed [15]. Among all these parameters, the light condition that is measured by the photosynthetic photon flux density (PPFD) is a main driving parameter in determining photosynthetic characteristics, and other biological and environmental conditions within the canopy [16] [17] [18]. The light response of photosynthesis of an individual leaf and the attenuation of PPFD in the canopy largely depend on the distribution of leaf area within the canopy [19] so that the detailed distribution of PPFD at different levels of the forest canopy is a prerequisite for the accurate estimation of the photosynthesis rate [20] [21].

Eco-physiological measurements in the processes of the forest ecosystem can provide crucial parameters for the canopy photosynthesis modeling [22] [23]. For example, the leaf area index (LAI), defined as the projected area of foliage per unit ground surface area $\left(\mathrm{m}^{2} \cdot \mathrm{m}^{-2}\right)$, is a very useful quantitative measure for the quantity of forest foliages [24] [25] and regulates the spatial and temporal distribution patterns of PPFD [26]. Thus, accurate measurements of seasonal variations of LAI and the leaf-level photosynthetic capacity that is affected by environment conditions (light, temperature, humidity and precipitation etc.) are required for estimating eco-physiological ecosystem processes (photosynthesis and respiration) [27] [28].

Cool-temperate deciduous forests are widely distributed in East Asia including southeastern Siberia, northern China, central and northern Japan and the Korean Peninsula [11] [29]. These forests are regarded as significant sinks for atmospheric $\mathrm{CO}_{2}$ [30]. In Korea, the forested region is located within the complex terrain of mountainous regions, which occupies about $65 \%\left(6.3 \times 10^{6}\right.$ hectare) of the whole territorial area. Deciduous and mixed forests of broad-leaved 
species are predominant with the area of $1.7 \times 10^{6}$ hectare and $1.9 \times 10^{6}$ hectare, respectively. They account for about $56 \%$ of all Korean forests. In particular, Mongolian oak (Quercus mongolica) forest stand is one of the typical deciduous broad-leaved forest types in the Korean Peninsula [31].

However, photosynthetic assimilation mechanisms, as well as biological processes and modeling at the forest stand level of $Q$. mongolica species in Korea have rarely been studied due to the lack of observed eco-physiological and phenological parameters for this forest, even though the $\mathrm{CO}_{2}$ sequestration behaviors in Q. mongolica forest stands may have a great effect on the balance of carbon budgets [32].

The purpose of this study is to estimate the canopy net photosynthesis rate of Q. mongolica forest stand for the growing period at the Nam-San ecologicalexperimental site with optimally derived photosynthetic light response curves and LAIs at several layers within the canopy with the use of the measured photosynthesis rates and the modified PPFDs by total plant area index (TPAI).

\section{Materials and Methods}

\subsection{Field Experimental Site}

Field experiments were conducted in a secondary Mongolian oak (Quercus mongolica) forest at the Nam-San Ecological Experimental site located in central Seoul city surrounded by urban complexes having various $\mathrm{CO}_{2}$ sources in the west-central part of the Korean Peninsula (Figure 1). The experimental site is located at $126^{\circ} 59^{\prime} \mathrm{E}$ and $37^{\circ} 33^{\prime} \mathrm{N}$ with a northeastern aspect, a gentle slope and an elevation of $220 \mathrm{~m}$ in a cool-temperate zone under the influence of Asian monsoon climate with a mild in springs and autumns, hot and humid in summers, and cold and snowy in winters. The climate data from Seoul Weather Station (belonging to Korea Meteorological Administration) close to the experimental site indicate that the annual mean air temperature and annual total precipitation are $11.8^{\circ} \mathrm{C}$ (minimum of $-3.4^{\circ} \mathrm{C}$ in January and maximum of $25.4^{\circ} \mathrm{C}$ in August) and $1369.8 \mathrm{~mm}$, respectively. A tower-based continuous measurement of $\mathrm{CO}_{2}$ flux between the forest and atmosphere, soil $\mathrm{CO}_{2}$ effluxes with automatic opening/closing chamber systems and various meteorological elements in the forest ecosystem have been made continuously since 2008 [33].

The vegetation at the site is classified as an approximately 49 - 55 years old deciduous broad-leaved forest, composed mainly of $Q$. mongolica. The predominant tree stand of $Q$. mongolica has an average diameter at breast height (DBH) of $23.2 \mathrm{~cm}$ and a total basal area of $22.1 \mathrm{~m}^{2} \cdot \mathrm{ha}^{-1}$. The continuous canopy height and density in Q. mongolica trees are about $15.1 \mathrm{~m}$ and $482 \mathrm{ha}^{-1}$, respectively. The mid- and understory vegetation under the dominant tree canopy of this site is rarely composed of few trees with Sorbus alnifolia, Styrax japonica, Acer pseudo-sieboldianum species. All leaves of these deciduous species at the site usually begin to flush in late April, and to fall in November. The starting times of leaf unfolding and shedding of Q. mongolica trees were, respectively 27 April and 30 October in 2010. More detailed descriptions of the Nam-San eco- 
(a)
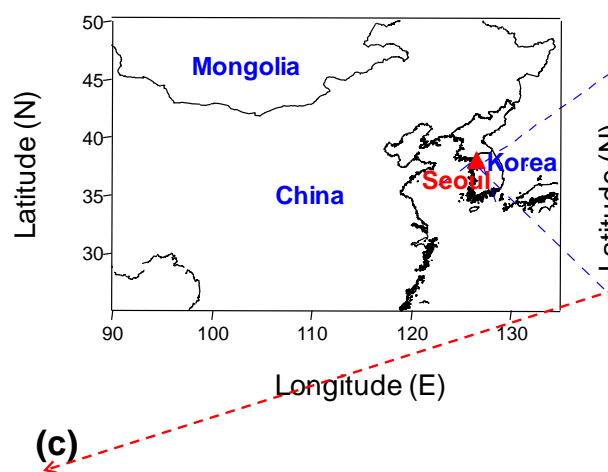

(b)
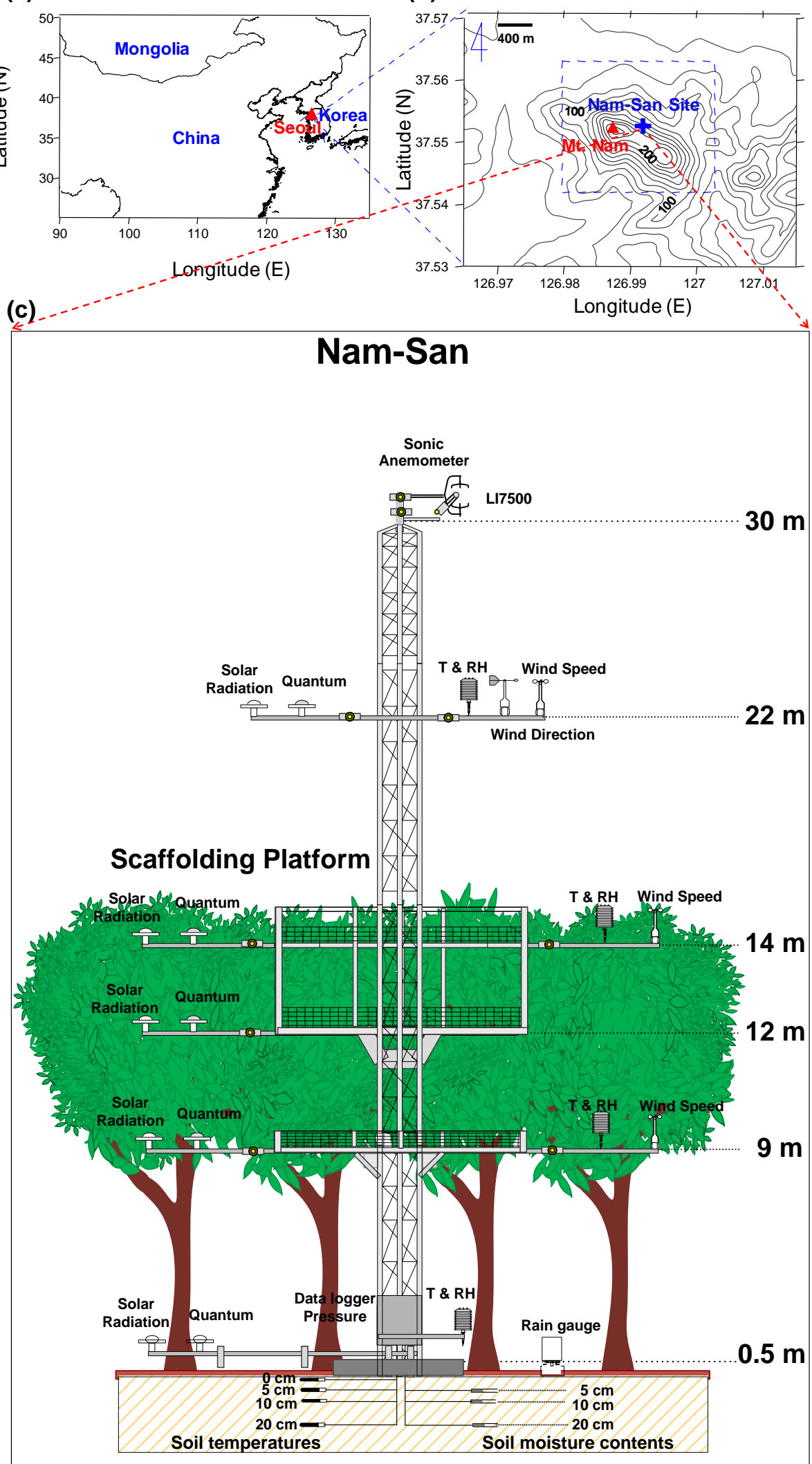

Figure 1. The geographical location of (a) Seoul, Korea. The topography of (b) Mt. Nam in Seoul with the indication of the ecological-experimental site (+, Nam-San site). A schematic view of (c) the canopy scaffolding tower at the Nam-San ecological-experimental site. 
logical-experimental site, including the soil properties and the geography are given in Joo et al. [33].

A canopy scaffolding tower with the canopy coverage of $3 \times 3 \mathrm{~m}$ was established in February 2010 in order to easily access each point of leaves and branches for field measurements in the dominant canopy (12 - $15 \mathrm{~m}$ tall) of six Q. mongolica trees (Figure 1(c)). Field measurements of leaf photosynthesis, leaf area and shoot structure at canopy profiles were conducted for several shoots of these dominant canopies throughout the growing season from early May to late October 2010.

\subsection{Environmental Measurements}

Air temperature and relative humidity were measured throughout the growing season by a platinum thermometer and a relative humidity sensor. Each of four sensors mounted on horizontal steel bars of the canopy tower at heights of 1.5, 9, 14 and $22 \mathrm{~m}$ above the ground within the $Q$. mongolica forest stand connected to a datalogger (CR1000; Campbell Scientific Inc., Utah, USA) to archive $10 \mathrm{~s}$ intervals data (Figure 1(c)).

The photosynthetic photon flux density (PPFD) and solar radiation were continuously measured with quantum sensors (LI-190SA; LI-COR, Inc., Lincoln, NE, USA) and pyranometers (LI-200SA; LI-COR, Inc., Lincoln, NE, USA), respectively, and each of the sensors mounted on horizontal steel bars of the tower at heights of 9,12, 14 and $22 \mathrm{~m}$ above the ground across the canopy tower in the Q. mongolica forest stand (Figure 1(c)) recorded continuously using a multi-channeled datalogger (CR1000; Campbell Scientific Inc., Utah, USA) at $1 \mathrm{~min}$ interval throughout the experimental period from April to November in 2010.

\subsection{Measurements of LAI and PPFD within the Canopy}

The forest canopy total plant area index (TPAI; the total plant area per unit of ground surface area) at different heights of $0.5,9,12,14$ and $15 \mathrm{~m}$ above the ground was measured with the plant canopy analyzer (LAI-2200; LI-COR, Inc., Lincoln, NE, USA) at the canopy scaffolding tower (Figure 1(c)) on 13 March, 15 April, 15 May, 17 June, 15 July, 17 August, 15 September, 20 October, and 10 November 2010, following the standard procedure described by the manual. This optical method measures not only the leaf area index (LAI; the total leaf area per unit of ground surface area) but also the wood silhouette area index (WSAI; the total stem and branch area per unit of ground surface area) within their field of view [34] [35] [36]. Therefore, the measured results are the total plant area index (TPAI) values that represent the sum of LAI and WSAI. When all the deciduous trees have no leaves, the WSAI value will be the same as the TPAI value observed with the LAI-2200. By subtracting this WSAI value from the TPAI values measured by the LAI-2200 allows to estimate the LAI values at any time $(\mathrm{TPAI}=\mathrm{LAI}+\mathrm{WSAI})[7][26]$.

The photosynthetic photon flux density (PPFD) for each month at heights of $0.5,9,12$, and $14 \mathrm{~m}$ above the ground within the same canopies using quantum 
sensors (LI-190SA; LI-COR, Inc., Lincoln, NE, USA) has also been measured simultaneously from March to November 2010 to find the relationship between PPFD and TPAI.

\subsection{Measurements of the Photosynthetic Light Response of Leaves}

Measurements of the leaf-level photosynthetic response to the incident light intensity are performed in leaves from the edge to the middle of the canopy at each target canopy level (the heights of target canopy levels are 9, 12, $14 \mathrm{~m}$ above the ground) in the $Q$. mongolica forest stand throughout the growing season from the full leaf expansion after the leaf unfolding in early May to senescence in late October. Only fully-expanded 3 leaves at each target canopy level are randomly selected from branches on three adjacent trees, accessed by a canopy scaffolding tower. Photosynthetic light responses for each sample of the intact leaves are measured six times a day for a 30-minute interval from 09:00 LST to 12:00 LST on a clear day and four days a month from May to October 2010 with two portable infrared gas analyzers (LI-6400; LI-COR, Lincoln, NE, USA). This method may avoid possible effects of photoinhibition of the intact leaves due to rising leaf temperature and water stress. The double-sided leaf chamber consists of an integrated infrared gas analyzer that can close a leaf area of $2 \times 3 \mathrm{~cm}$. The various light intensities (PPFD, $0-2000 \mu \mathrm{mol} \cdot \mathrm{m}^{-2} \cdot \mathrm{s}^{-1}$ ) inside the leaf chamber are provided by a red-blue LED light source (LI-6400-02B; LI-COR, Lincoln, NE, USA) of the LI- 6400 .

In each measurement, first, the sample leaves inside the chamber are kept with a PPFD of $1500 \mu \mathrm{mol} \cdot \mathrm{m}^{-2} \cdot \mathrm{s}^{-1}$ until equilibrium. Second, the incident PPFD is regulated at ten intensities, changing from high to low intensity (1800, 1500, $1000,700,500,300,150,100,50$, and $0 \mu \mathrm{mol} \cdot \mathrm{m}^{-2} \cdot \mathrm{s}^{-1}$ ) with the LED source. In each change of light intensity, the PPFD is kept constant until the equilibrium of the leaves. The air flow rate through the chamber is maintained at 500 $\mu \mathrm{mol} \cdot \mathrm{m}^{-2} \cdot \mathrm{s}^{-1}$. The chamber is maintained at nearly the same ambient $\mathrm{CO}_{2}$ concentration of $370 \mathrm{ppm}$ via the built-in $\mathrm{CO}_{2}$ mixer and the relative humidity of $70 \%-80 \%$. Air temperature of the leaf chamber is adjusted to the mean daytime air temperature of about one week before each measurement day. During these light response measurements, the air temperature inside the leaf chamber in May, June, July, August, September and October are maintained in the range of $20^{\circ} \mathrm{C}-22^{\circ} \mathrm{C}, 24^{\circ} \mathrm{C}-26^{\circ} \mathrm{C}, 26^{\circ} \mathrm{C}-28^{\circ} \mathrm{C}, 26^{\circ} \mathrm{C}-28^{\circ} \mathrm{C}, 23^{\circ} \mathrm{C}-25^{\circ} \mathrm{C}$ and $16^{\circ} \mathrm{C}-$ $18^{\circ} \mathrm{C}$, respectively.

\subsection{Statistical Analysis}

Values of parameters in all equations were estimated by fitting the data to the appropriate functions using the exponential decay regression and modified nonlinear least squares routine. All statistical analyses were performed with SYSTAT statistical analysis software. The statistical significances for environmental properties and photosynthetic parameters were accepted at $\alpha=0.05$ (SigmaPlot ${ }^{\circledR} 12$, SPSS Inc. CA, USA). 


\section{Results}

\subsection{Seasonal Variations of Environmental Conditions}

Figure 2 shows the seasonal variations of the daily total PPFD at the height of 22 $\mathrm{m}$ above the canopy (Figure 2(a)), the precipitation amount and soil moisture content at the 15-cm depth (Figure 2(b)), and the daily mean air temperature at the height of $14 \mathrm{~m}$ and the soil temperature at the 5-cm depth (Figure 2(c)). During the peak growing period from June to August 2010, the maximum and minimum values of daily total PPFD (Figure 2(a)) were about 33.4 and $3.4 \mathrm{~mol}$ $\mathrm{m}^{-2}$ day $^{-1}$, respectively with large seasonal variations of them in association with weather conditions such as cloudiness and precipitation events (Figure 2(a) and Figure 2(b)). The daily total PPFD values were highest in June, and then gradually decreased towards autumn due to the decrease of the solar altitude and the
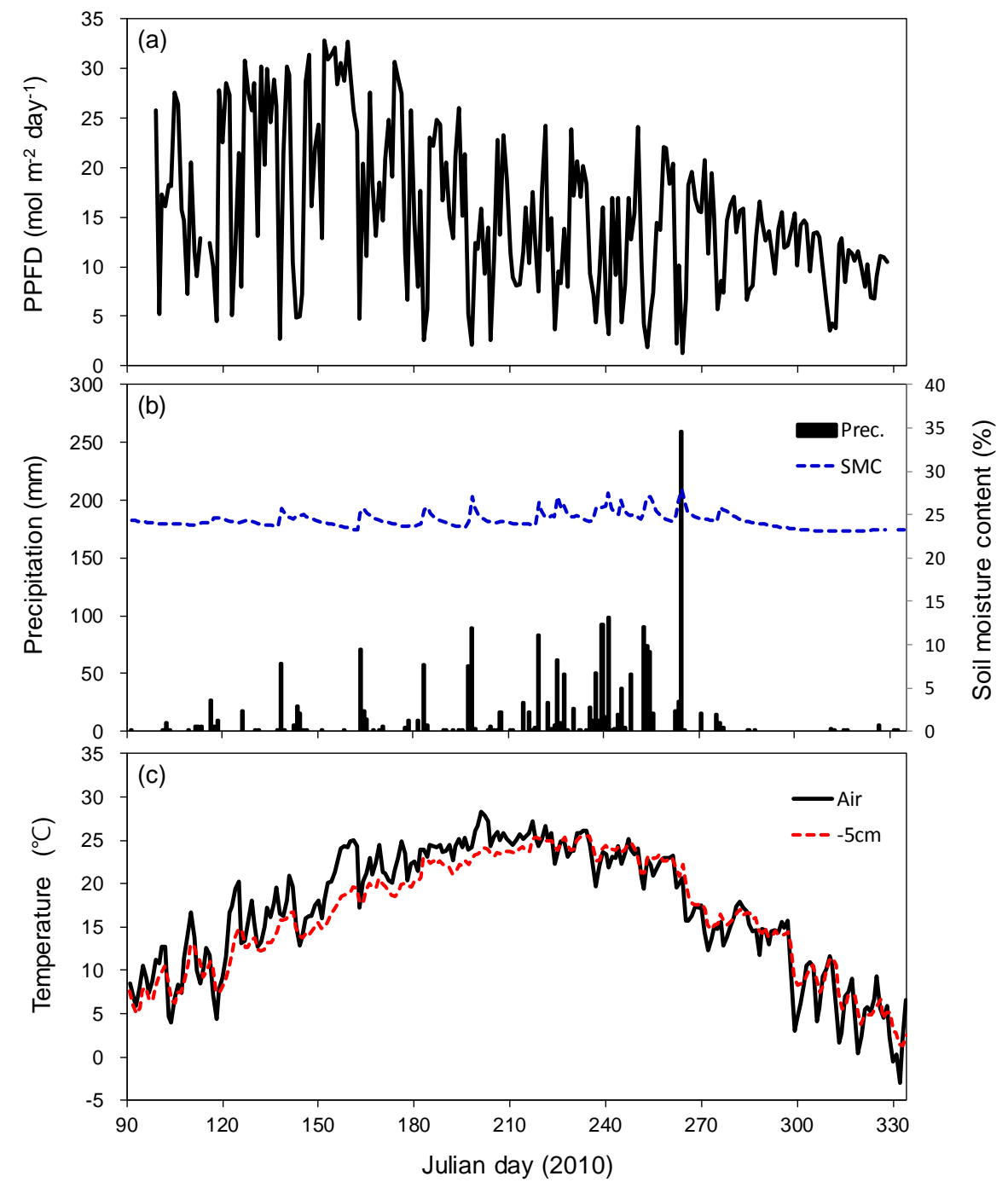

Figure 2. Seasonal variations of (a) the daily total PPFD at the top of the canopy $\left(\mathrm{mol} \cdot \mathrm{m}^{-2} \cdot\right.$ day $\left.^{-1}\right)$, (b) precipitation $(\mathrm{mm})$ and soil moisture content $(\%)$ at the $15-\mathrm{cm}$ depth, and (c) the daily mean air temperature $\left({ }^{\circ} \mathrm{C}\right)$ and soil temperature at the $5-\mathrm{cm}$ depth $\left({ }^{\circ} \mathrm{C}\right)$ measured in the $Q$. mongolica forest at the Nam-San ecological-experimental site from April to November 2010. 
sunshine duration. During the experimental period, the site was influenced by a typhoon (Day 245) and a heavy rainfall event (Day 264) in September 2010 (Figure 2(b)). The total precipitation in July and August 2010 was $837.9 \mathrm{~mm}$ (44\% of the annual total precipitation) and $671.5 \mathrm{~mm}$ in September 2010 (35\% of the annual total precipitation). The soil moisture content exhibited no distinct seasonal changes. However, after precipitation events, the soil moisture content in the Q. mongolica forest site increased rapidly during the growing season from late May to early September 2010 (Figure 2(b)). The air and soil temperatures measured at the Nam-San site showed significant seasonal variations (Figure $2(\mathrm{c}))$. The trend of soil temperature at the $5 \mathrm{~cm}$ depth varied similarly to those of air temperature at the height of $14 \mathrm{~m}$ during the whole experiment period. The daily mean air temperature increased steadily until mid-summer to reach a mean maximum air temperature of $28.3^{\circ} \mathrm{C}$ (Day 201) in July, and then decreased gradually throughout autumn.

\subsection{LAI and PPFD within the Canopy}

Figure 3(a) shows the measured TPAI values at different heights from March to November. It shows that the canopy of $Q$. mongolica forest is in the mature state during the period of July and August and the leaves in the mature state extend more than $15 \mathrm{~m}$ above the ground. The measured values of the wood silhouette area index (WSAI) at different canopy heights of $0.5,9,12,14$, and $15 \mathrm{~m}$ above the ground in the $Q$. mongolica forest stand at the experimental site were 1.2, $1.0,0.7,0.5$, and $0.0 \mathrm{~m}^{2} \mathrm{~m}^{-2}$ on 13 March 2010 (no leaf season), respectively. By subtracting this WSAI value from TPAI measured at different canopy heights (Figure 3(a)), the true LAI values are obtained at different canopy heights. Figure 3 (b) shows the seasonal variation of the true LAI at several different canopy heights. The LAI values within the canopy layers of $Q$. mongolica forest stand show clearly seasonal changes during the leaf expansion period of late April to the leaf-litter fall period of November with a maximum of $4.6 \mathrm{~m}^{2} \mathrm{~m}^{-2}$ (observed at $0.5 \mathrm{~m}$ height above the ground) in July (Figure $3(\mathrm{~b})$ ). During the experimental period, leaves and branches of the $Q$. mongolica forest canopy at the site were disturbed suddenly by a typhoon on 2 September 2010 .

The measured PPFDs (Figure 3(c)) around the local noon for each month at heights of $0.5,9,12,14 \mathrm{~m}$ and above the canopy $(22 \mathrm{~m})$ are plotted with the measured TPAIs (Figure 3(a)) at the same heights and given in Figure 4. The scatter plots at each month in Figure 4 clearly indicate that the Beer-Lambert's law [37] [38] is applicable for the relationship between PPFD and TPAI, which is given as

$$
\mathrm{PPFD}=\alpha \exp (-\beta F)
$$

where $\alpha$ is the coefficient that corresponds to the measured PPFD above the canopy, PPFD and $F$ are the measured PPFD at the local noon and TPAI at the target canopy level (heights of $0.5,9,12,14 \mathrm{~m}$ and above canopy) respectively, and $\beta$ is the apparent light extinction coefficient.

The observed data quite well satisfy the optimal regression Equation (1) with 
$r^{2}$ values ranging from 0.98 to 0.99 with $p<0.001$. During the whole experimental period, the extinction coefficient $(\beta)$ values vary from 0.57 to 0.97 with the large value in the early growing season of May and the late growing season of September and October before the leaf-litter fall period (November). During the peak growing season (June-August), $\beta$ values are relatively constant in the range of $0.57-0.59$. The large light extinction coefficients $(\beta)$ in the early (May) and the late growing season (October) may be attributed to WSAI that occupies more than $40 \%$ of TPAI, suggesting more effectiveness of branches and stems on the extinction of PPFD. The optimal regression function of Equation (1) in Figure 4 makes it possible to estimate the light extinction coefficient $\beta$ that is an
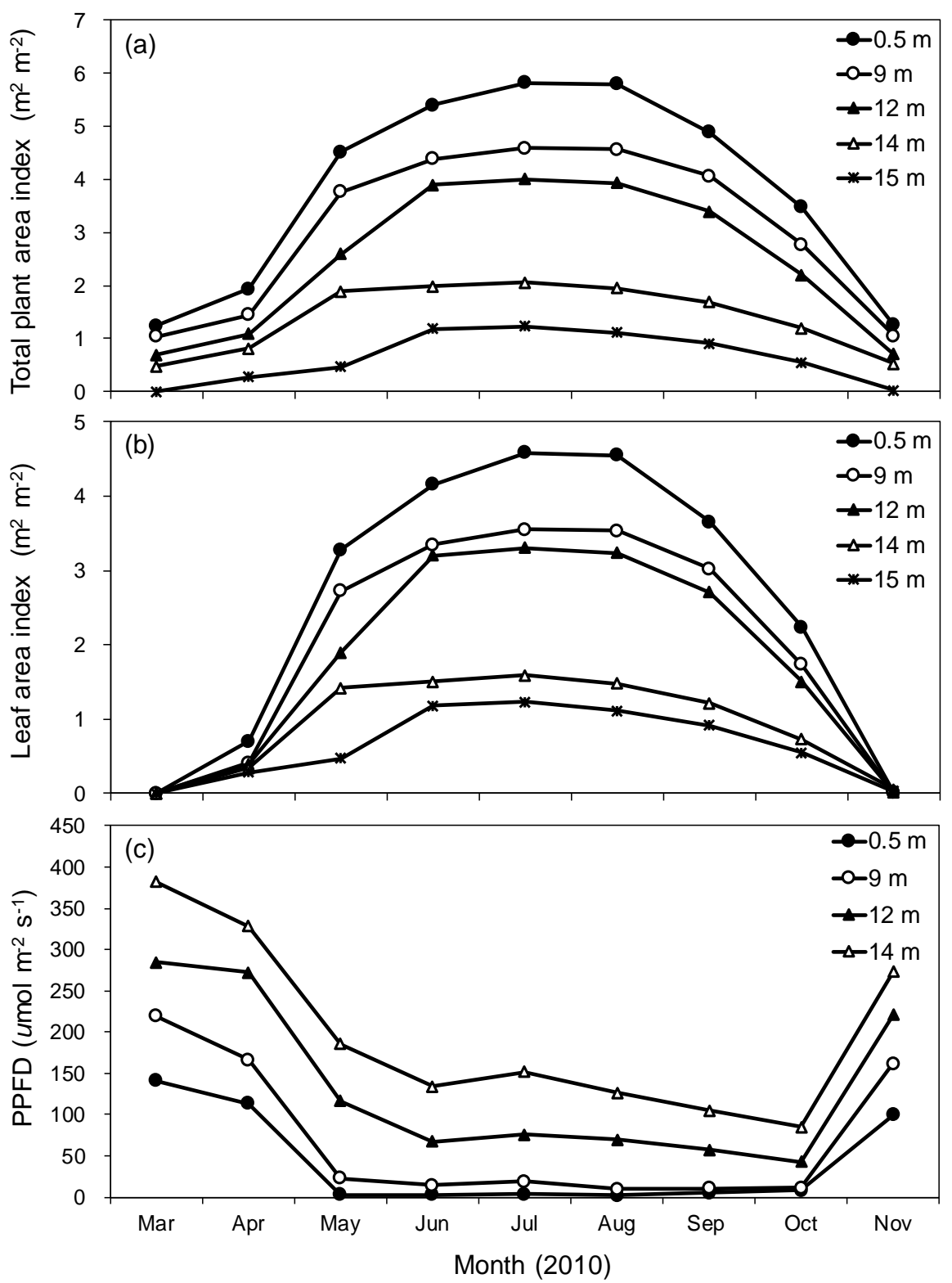

Figure 3. Monthly variations of (a) the total plant area index (TPAI, $\mathrm{m}^{2} \cdot \mathrm{m}^{-2}$ ), (b) the leaf area index (LAI, $\mathrm{m}^{2} \cdot \mathrm{m}^{-2}$ ) and (c) the PPFDs $\left(\mu \mathrm{mol} \mathrm{m} \mathrm{m}^{-2} \mathrm{~s}^{-1}\right.$ ) measured at $0.5 \mathrm{~m}(-), 9 \mathrm{~m}$ $(\boldsymbol{\infty}), 12 \mathrm{~m}(\boldsymbol{-}), 14 \mathrm{~m}(\boldsymbol{-})$ and $15 \mathrm{~m}(\boldsymbol{*})$ canopy heights of $Q$. mongolica forest at the Nam-San ecological-experimental site from March to November 2010. 
(a) May

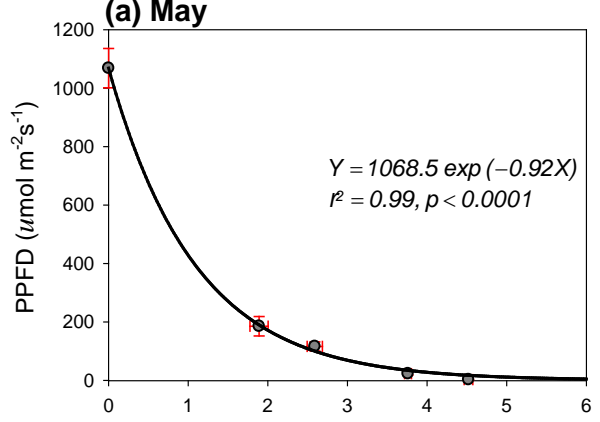

(c) July
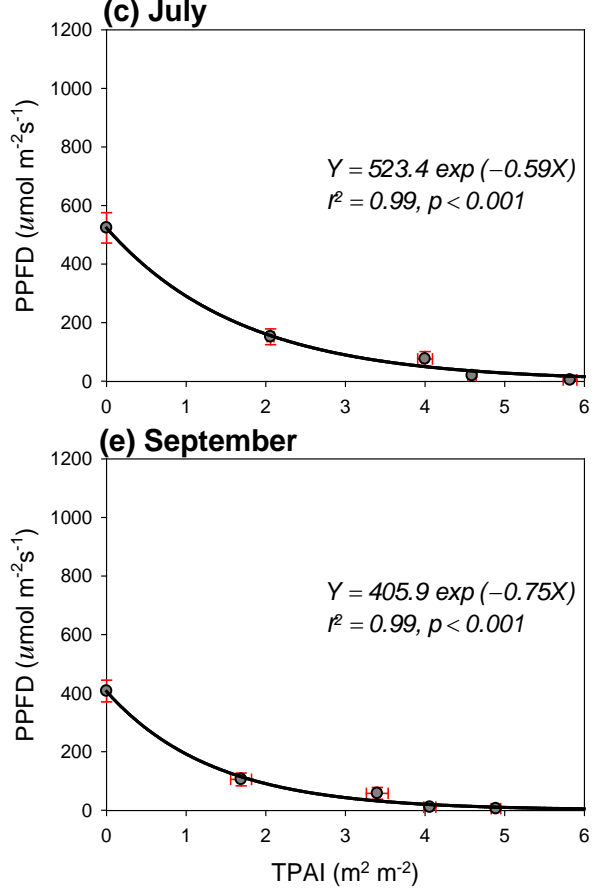

(b) June
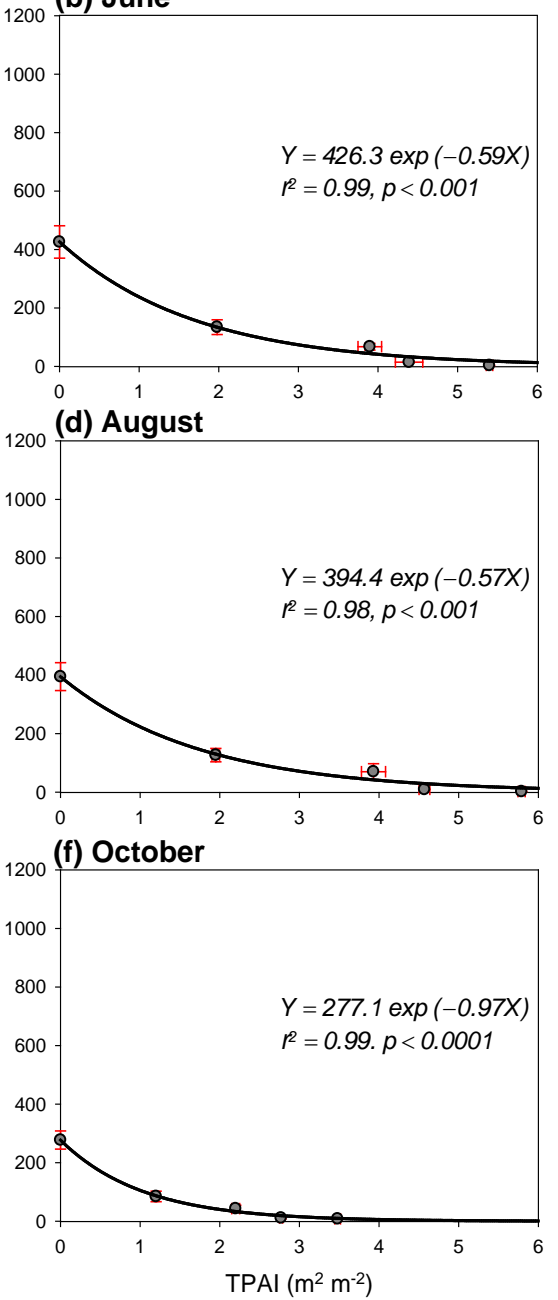

Figure 4. The scatter plots of the measured PPFD $\left(\mu \mathrm{mol} \cdot \mathrm{m}^{-2} \cdot \mathrm{s}^{-1}\right)$ versus TPAI $\left(\mathrm{m}^{2} \cdot \mathrm{m}^{-2}\right)$ at different canopy heights for the month of (a) May, (b) June, (c) July, (d) August, (e) September, and (f) October 2010 in the Q. mongolica forest. The optimal regression curve with $r^{2}$ and $p$ (significant level) values in each month is indicated. The vertical and horizontal bars show standard deviations of the means.

index of light availability in a canopy layer of $Q$. mongolica forest stand with the observed PPFD and $F$ values at the local noon.

The distributions and temporal variations of relative PPFD (PPFD under the canopy relative to that above the canopy) at different canopy levels can be obtained by taking into account the light path-length through the canopy that depends on the solar elevation angle ( $(5)$. Therefore, $F$ value in Equation (1) should be changed to $F^{\prime}$ in such a way that

$$
F^{\prime}=F / \sin \hbar
$$

$F^{\prime}$ is referred to the "effective TPAI" hereafter. Equation (2a) allows to evaluate the diurnal and seasonal variations of $(\mathrm{PPFD})_{t}$ (referred to the "available PPFD" hereafter) due to the temporal change of the light path-length through the canopy. At the local noon $\left(\hbar=90^{\circ}\right) F^{\prime}=F$, i.e., the effective TPAI is the same as the observed one $(F)$ that is taken at the local noon. 
The solar elevation angle is given by

$$
\sin \hbar=\sin \delta \sin \phi+\cos \delta \cos \phi \cos \omega
$$

where $\delta$ is the solar declination angle, $\phi$ the geographical latitude and $\omega$ the hour angle.

The solar declination angle (in degree) is given by

$$
\delta=23.45 \sin [360 / 365(\mathrm{~d} n+284)]
$$

where $\mathrm{d} n$ is the Julian day number.

The temporal varying PPFD (available PPFD, (PPFD) $)_{t}$ at the target canopy level is given by

$$
(\mathrm{PPFD})_{t}=\alpha \exp \left(-\beta F^{\prime}\right)=\alpha \exp (-\beta F / \sin \hbar)
$$

The available PPFD $\left((\mathrm{PPFD})_{t}\right)$ at the target canopy level is obtained with the hourly measured PPFD above the canopy $(\alpha)$ and the measured TPAI $(F)$ at the target canopy level for a given day with Equation (3).

\subsection{Photosynthetic Light Response Curve}

Figure 5 shows the measured net photosynthesis rates (the difference between the photosynthesis rate and the leaf respiration rate) with respect to light intensities (PPFD, $0-2000 \mu \mathrm{mol} \cdot \mathrm{m}^{-2} \cdot \mathrm{s}^{-1}$ ). The optimal regression curve which is called the photosynthetic light response curve is obtained by best fitting the scatter plots in Figure 5 with the combined function of the hyperbola and the linear functions at each month. This chosen function is best fitted the observed data with $r^{2}$ values ranging from 0.994 to 0.996 with $p<0.001$ for the whole growing period.

\subsection{Estimation of Total Canopy Net Photosynthesis Rate}

To estimate photosynthesis rate within the canopy, the canopy is divided into five layers; Layer 1 extends from $15 \mathrm{~m}$ to the top of canopy, Layer 2 from $14 \mathrm{~m}$ to $15 \mathrm{~m}$, Layer 3 from $12 \mathrm{~m}$ to $14 \mathrm{~m}$, Layer 4 from $9 \mathrm{~m}$ to $12 \mathrm{~m}$ and Layer 5 from 0.5 $\mathrm{m}$ to $9 \mathrm{~m}$ above the ground (Figure $1(\mathrm{c})$ ). The available PPFD $\left((\mathrm{PPFD})_{t}\right)$ in each layer is estimated by averaging the estimated (PPFD) $s$ at two levels that delineate each layer. The net photosynthesis rate in each layer is obtained from the photosynthetic light response curve (Figure 5 ) with the use of available (PPFD) $s$ in each layer and multiplying the layer LAI (the difference of LAI between two adjacent levels) (Figure 3(b)) in each layer. The summation of the net photosynthesis rate for all layers in the canopy at each time yields to the hourly total canopy net photosynthesis rate. This is illustrated in Figure 6 on 21 June 2010.

\section{Discussion}

\subsection{Photosynthetic Light Response Curves for Leaves of Q. mongolica}

Many studies have generally used the non-rectangular hyperbola function as the photosynthetic light response curve [11] [39] [40]. However, this function can- 
not be used to estimate the net photosynthesis rate when the incident PPFD value exceeds the light saturation point (LSP) as seen in Figure 5(a) and Figures 5(d)-(f). The light saturation point (LSP) is represented by the PPFD value when the net photosynthesis rate becomes maximum. That is about $1000 \mu \mathrm{mol} \cdot \mathrm{m}^{-2} \cdot \mathrm{s}^{-1}$ in the early growing month of May when the leaf is young (Figure 5(a)), and those in the mid and late growing period in August (Figure 5(d)), September (Figure 5(e)) and October (Figure 5(f)) are respectively 1083, 957 and 523 $\mu \mathrm{mol} \cdot \mathrm{m}^{-2} \cdot \mathrm{s}^{-1}$. However, for the matured leaves in June (Figure $5(\mathrm{~b})$ ) and July (Figure 5(c)), there is no LSP within the measured PPFD value.

(a) May

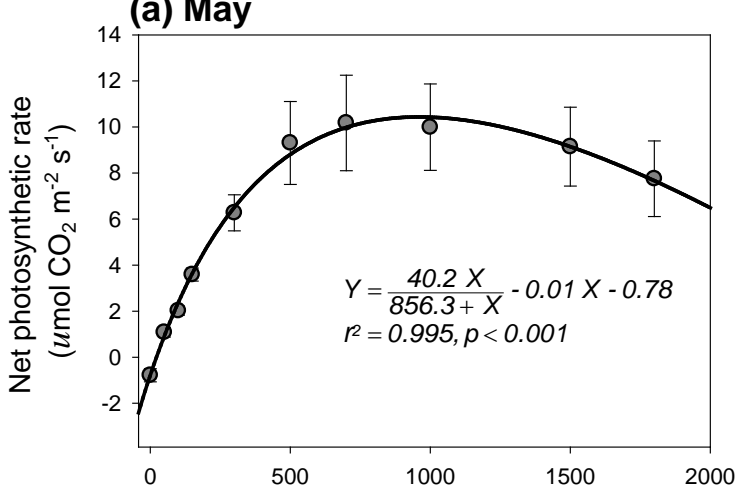

(c) July

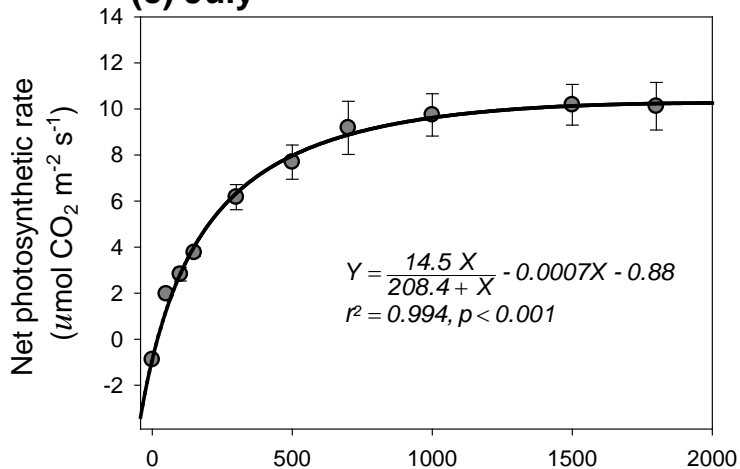

(e) September

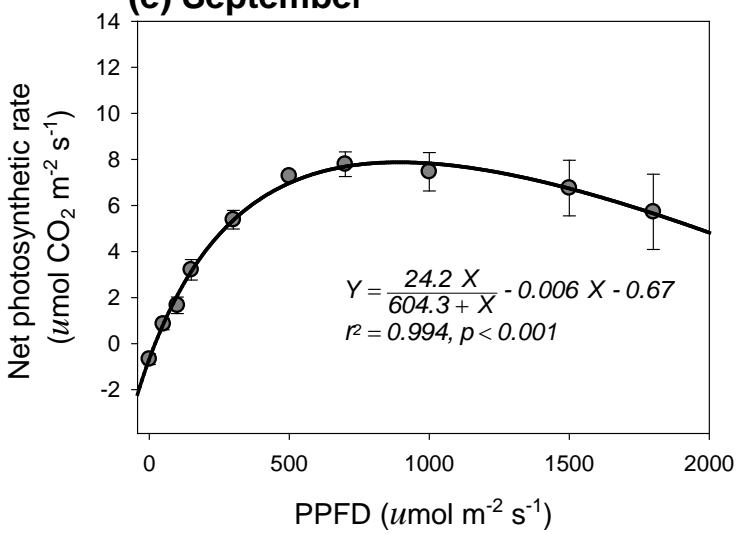

(b) June

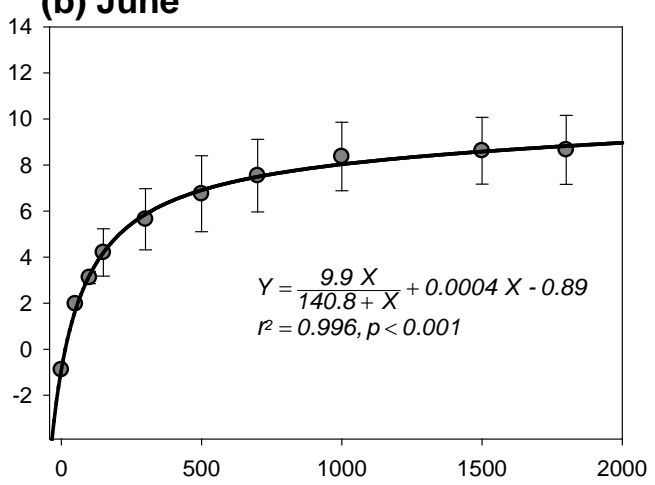

(d) August

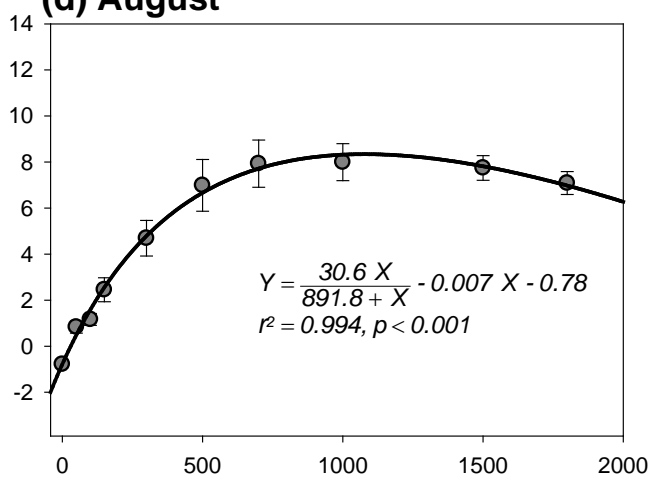

(f) October

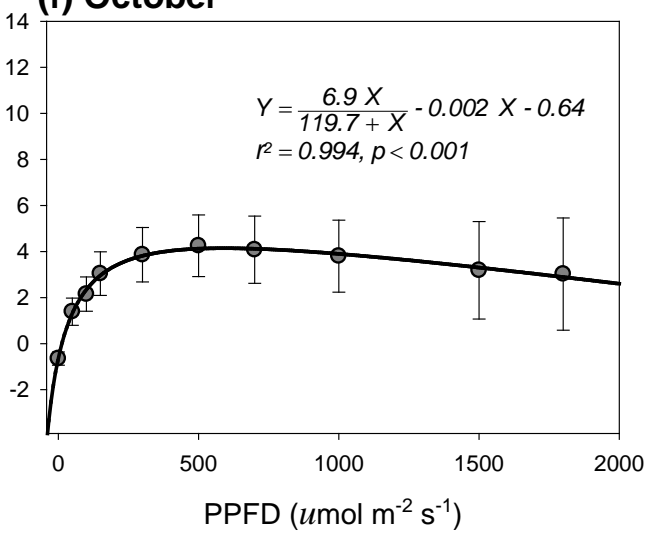

Figure 5. The scatter plots of the observed net photosynthesis rate $\left(\mu \mathrm{mol} \mathrm{CO}_{2} \mathrm{~m}^{-2} \cdot \mathrm{s}^{-1}\right)$ for the leaf of $Q$. mongolica against PPFD $\left(\mu \mathrm{mol} \cdot \mathrm{m}^{-2} \cdot \mathrm{s}^{-1}\right.$ ) with the optimal regression curves for the month of (a) May, (b) June, (c) July, (d) August, (e) September and (f) October 2010 at the Nam-San ecological-experimental site. The optimal regression curve with $r^{2}$ and $p$ (significant level) values in each month is indicated. The vertical bars show standard deviations of the means. 
(a)

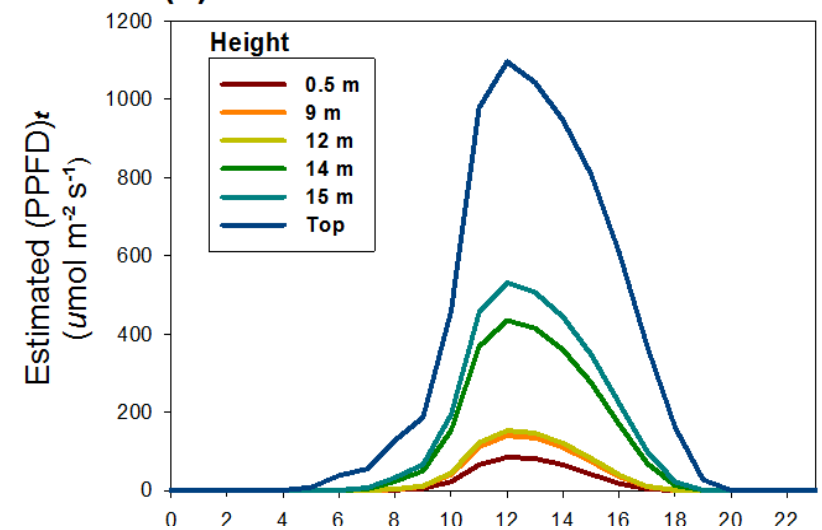

(b)

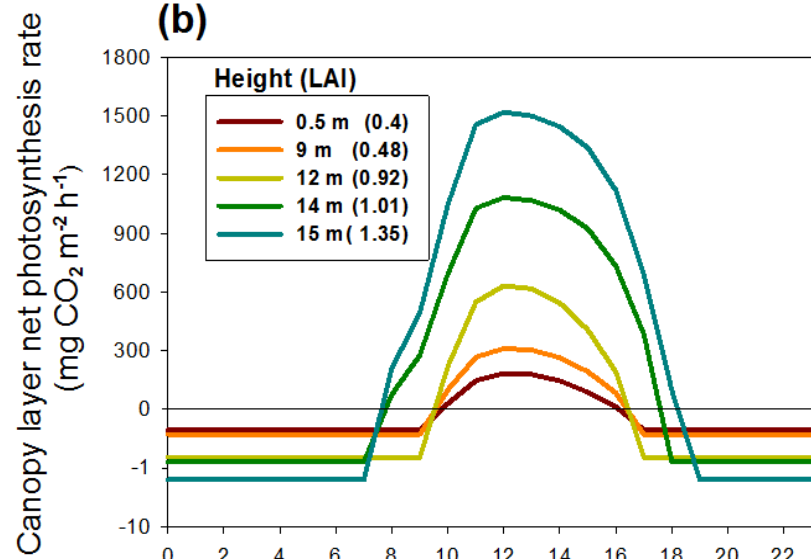

(c)

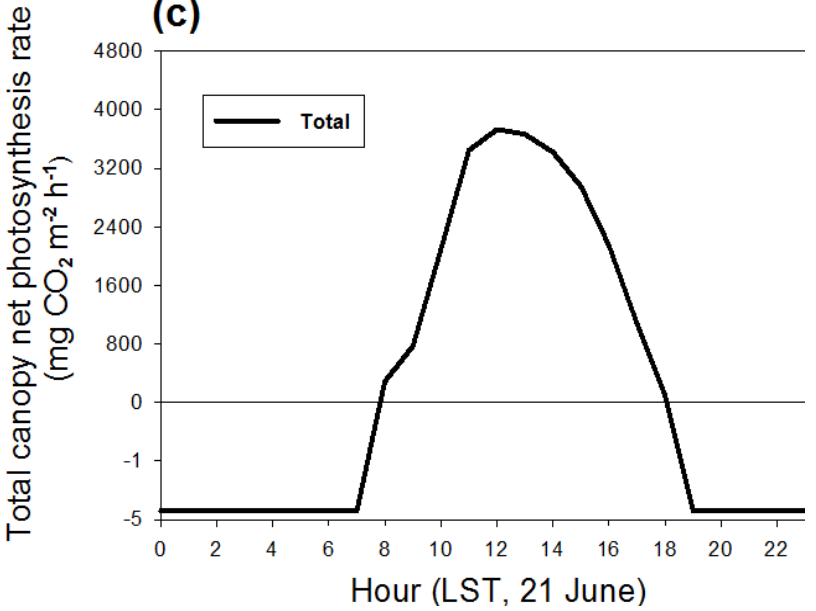

Figure 6. Diurnal variations of the estimated (a) (PPFD) thesis rate at different canopy layers, and (c) total canopy net photosynthesis rate in the Q. mongolica forest stand on 21 June 2010 .

This may be associated with the limitation of the canopy transpiration that is controlled by the stomatal resistance, which in turn depends on the atmospheric conditions of the vapour pressure deficit, air temperature and PPFD, availability of soil moisture in the root zone, and the vegetation types [41]. Among these factors higher air temperature than that at LSP may cause the increase of stomatal resistance thereby decreasing the net photosynthesis rate with the further increase of PPFD in the early growing (young leaf) and late growing (leaf senes- 
cent) periods. Figure 7 illustrates air temperature limitation for the net photosynthesis rate on 20 May when other factors are not in the limiting range for the stomatal resistance. The diurnal changes of air temperature and the net photosynthesis rate are directly related to those of PPFD (Figure 7). However, air temperature on 20 May is lagged 3 hours compared to that of PPFD so that the 3-hr lagged air temperature is plotted on the time axis of the PPFD to coincide the maximum value of PPFD with that of air temperature. When the air temperature exceeds $24.0^{\circ} \mathrm{C}$ at LSP $\left(944 \mu \mathrm{mol} \cdot \mathrm{m}^{-2} \cdot \mathrm{s}^{-1}\right)$ at $10: 00 \mathrm{LST}$ on 20 May the net photosynthesis rate is decreasing with the increase of air temperature and/or PPFD (Figure 7).

The observed monthly temperature range (observed maximum PPFD) in 2010 at this site is $6^{\circ} \mathrm{C}-26^{\circ} \mathrm{C}\left(1349 \mu \mathrm{mol} \cdot \mathrm{m}^{-2} \cdot \mathrm{s}^{-1}\right)$ in May, $14^{\circ} \mathrm{C}-30^{\circ} \mathrm{C}(1360$ $\left.\mu \mathrm{mol} \cdot \mathrm{m}^{-2} \cdot \mathrm{s}^{-1}\right)$ in June, $21^{\circ} \mathrm{C}-32^{\circ} \mathrm{C}\left(1280 \mu \mathrm{mol} \cdot \mathrm{m}^{-2} \cdot \mathrm{s}^{-1}\right)$ in July, $19-32^{\circ} \mathrm{C}(1267$ $\left.\mu \mathrm{mol} \cdot \mathrm{m}^{-2} \cdot \mathrm{s}^{-1}\right)$ in August, $9^{\circ} \mathrm{C}-30^{\circ} \mathrm{C}\left(1162 \mu \mathrm{mol} \cdot \mathrm{m}^{-2} \cdot \mathrm{s}^{-1}\right)$ in September and $1^{\circ} \mathrm{C}$ $20^{\circ} \mathrm{C}\left(976 \mu \mathrm{mol} \cdot \mathrm{m}^{-2} \cdot \mathrm{s}^{-1}\right)$ in October. These observed maximum PPFDs exceed the LSP values in May, August and September, likewise the temperatures in these months will exceed the optimum temperature for the photosynthesis (Figure 7) so that the photosynthesis rate of the Q. mongolica leaf may be restricted by the exceeding temperature. However, the observed PPFDs in June and July are within the LSP values so that the photosynthesis rate is not limited by the light intensity (or air temperature).

To determine the environmental temperature at LSP (the maximum temperature yields to maximum net photosynthesis rate), the percent occurrence frequencies of PPFD and air temperature in each month are constructed and then the cumulative occurrence frequency at the LSP value is found in the occurrence frequency distribution of PPFD (Figure 8) since the higher PPFD is related to the higher air temperature (Figure 7). The cumulative occurrence frequency at the LSP value in the occurrence frequency distribution of PPFD (Figure 8(a)) is assumed to be the same as that in the occurrence frequency distribution of air temperature (Figure 8(b)). This leads to determine the air temperature at LSP as shown in Figure 8(b). Above this temperature the net photosynthesis rate of the Q. mongolica leaf will be reduced due to the increased stomatal resistance caused by high temperature.

It is worthwhile to note that the light compensation point (LCP) that is represented by the minimum PPFD value for the leaf to photosynthesis against leaf respiration (Figure 5) shows a significant seasonal variation with relatively high PPFD $\left(20-21 \mu \mathrm{mol} \cdot \mathrm{m}^{-2} \cdot \mathrm{s}^{-1}\right)$ in the early (May) and later growing periods (September and October), whereas the relatively low PPFD $\left(14 \mu \mathrm{mol} \cdot \mathrm{m}^{-2} \cdot \mathrm{s}^{-1}\right)$ in the matured leaf period (June and July). However, the highest PPFD (30 $\left.\mu \mathrm{mol} \cdot \mathrm{m}^{-2} \cdot \mathrm{s}^{-1}\right)$ at LCP in August might be attributed to the unusual high soil moisture contents in association with frequent occurrences of precipitation events at the site (Figure 2(b)) since the high soil moisture content enhances the soil respiration rate [33]. However, the impact of high soil moisture content on the photosynthesis rate requires further experimental study. 


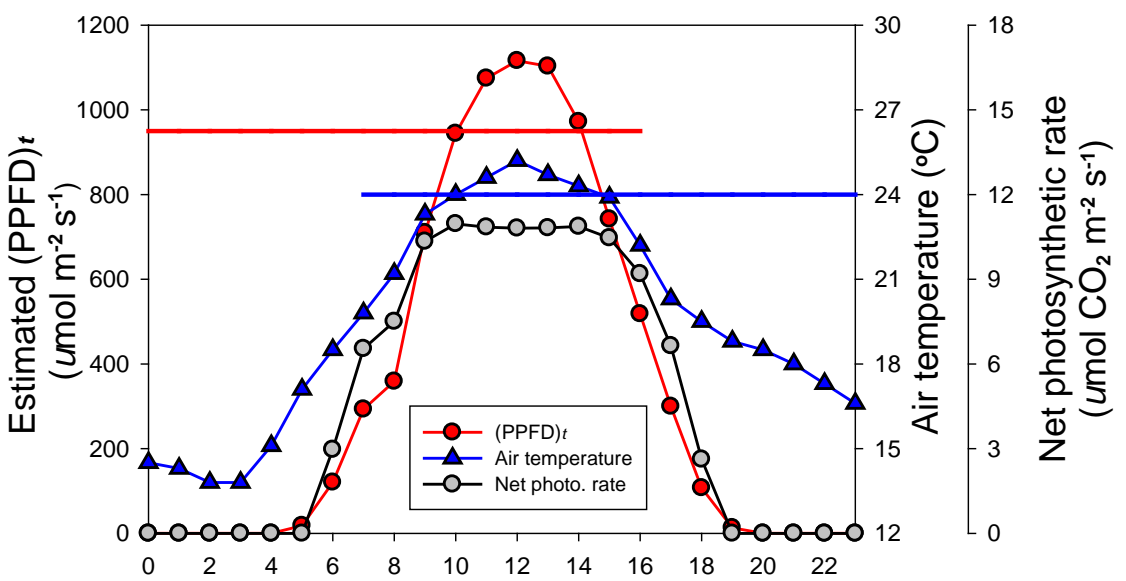

Hour (LST, 20 May)

Figure 7. Diurnal changes of (PPFD) ${ }_{t}\left(-, \mu \mathrm{mol} \cdot \mathrm{m}^{-2} \cdot \mathrm{s}^{-1}\right)$, the net photosynthesis rate $\left(-\mathrm{O}, \mu \mathrm{mol} \cdot \mathrm{CO}_{2} \cdot \mathrm{m}^{-2} \cdot \mathrm{s}^{-1}\right)$ and air temperature $\left(-,{ }^{\circ} \mathrm{C}\right)$ at the experimental site on 20 May 2010. The $3 \mathrm{hrs}$ lagged air temperature (LST-3hr) compared to (PPFD) is plotted on the same $\mathrm{x}$-axis of (PPFD) ${ }_{t}$ to show the direct response of air temperature to the (PPFD) forcing. The red line (-) and the blue line (-) indicate the (PPFD) ${ }_{t}$ value and the air temperature at the light saturation point (LSP), respectively.
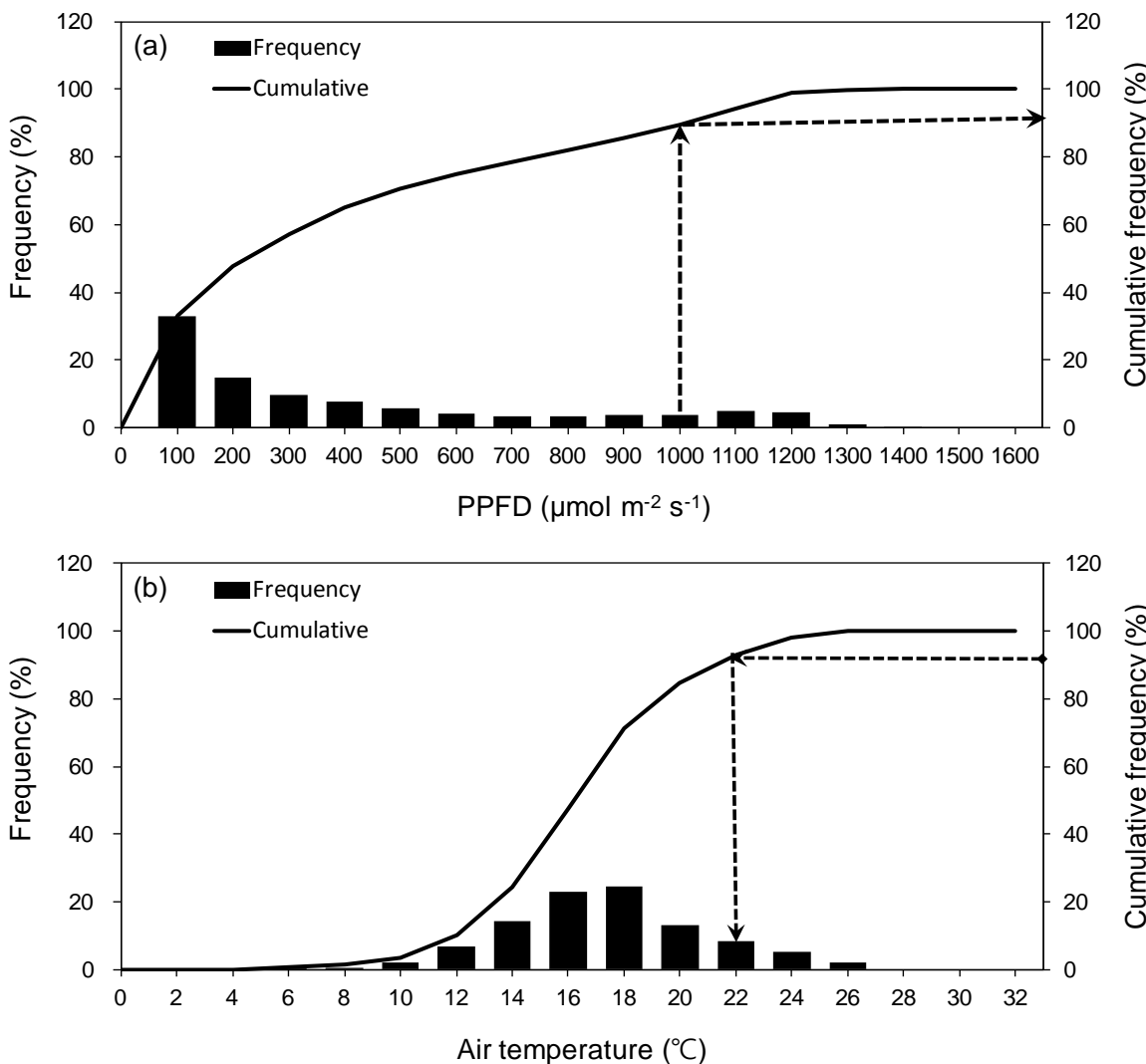

Figure 8. The distributions of the percent occurrence frequency ( $\square$ ) with the cumulative occurrence frequency ( $)$ of (a) PPFD $\left(\mu \mathrm{mol} \cdot \mathrm{m}^{-2} \cdot \mathrm{s}^{-1}\right)$ and (b) air temperature $\left({ }^{\circ} \mathrm{C}\right)$ at the Q. mongolica forest of the Nam-San site in May 2010. The data measured at every one minute interval are used for this analysis. The arrow shows the way to determine the cumulative frequency at LSP $\left(1000 \mu \mathrm{mol} \cdot \mathrm{m}^{-2} \cdot \mathrm{s}^{-1}\right)$ while that in (b) shows the way to determine the air temperature at LSP determined in (a). 
Table 1 summaries the physiological trait of photosynthetic light response of Q. mongolica leaves derived in 2010 at the experimental site. The statistical results in August in Table 1 may be different from those of the normal year, especially the LCP value in August which is much higher than those values in June and July. The continuous measurement of the photosynthesis rate with other environmental factors at the site will clarify these uncertainties.

\subsection{Seasonal Variation of Total Canopy Net Photosynthesis Rate}

Using the PPFD measured above the canopy (Figure 2(a)), (PPFD) $s$ at 15, 14, 12,9 and $0.5 \mathrm{~m}$ heights within the canopy are estimated by the empirically obtained light attenuation function (Figure 4) due to TPAI and then the net photosynthesis rates at these heights are estimated using the photosynthetic light response curves in Figure 5 with estimated (PPFD), The canopy layer net photosynthesis rates are estimated by the net photosynthesis rate multiplied by the layer LAI in each layer as in Figure 6.

Figure 9 shows the time series of the estimated daily total canopy net photosynthesis rates in the $Q$. mongolica forest stand. The daily total canopy net photosynthesis rate increases remarkably from the spring season (a range of 1.7 $28.3 \mathrm{~g} \mathrm{CO}_{2} \mathrm{~m}^{-2}$. day ${ }^{-1}$ in May) to the early summer season (a range of $9.5-36.2 \mathrm{~g}$ $\mathrm{CO}_{2} \mathrm{~m}^{-2} \cdot$ day $^{-1}$ in June), and then sharply decreased from August to October (a range of $0.4-25.1 \mathrm{~g} \mathrm{CO}_{2} \mathrm{~m}^{-2}$. day ${ }^{-1}$ in September). The sharp decrease of the total canopy net photosynthesis rate in August is due to the prolonged cloudy weather condition in association with rainfall events during this period (Figure 2(b)).

Figure 10 shows comparison of seasonal variations of the monthly total ca-

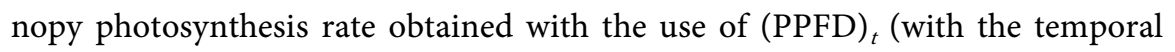
change of solar elevation angle) and PPFD (without change of it) at the site. The estimated minimum canopy net photosynthesis rate with (PPFD) ${ }_{t}$ (PPFD) is about $0.23 \mathrm{~kg} \mathrm{CO}_{2} \mathrm{~m}^{-2}$ month $^{-1}\left(0.27 \mathrm{~kg} \mathrm{CO}_{2} \mathrm{~m}^{-2}\right.$ month $\left.^{-1}\right)$ in October, while the

Table 1. Monthly variations of characteristic features of photosynthetic light response of Q. mongolica leaves at the Nam-San ecological-experimental site during the whole growing season from May to October in 2010.

\begin{tabular}{|c|c|c|c|c|c|c|}
\hline Parameter & May & June & July & August & September & October \\
\hline $\begin{array}{l}\text { Light conpensation point (LCP) } \\
\qquad\left(\mu \mathrm{mol} \cdot \mathrm{m}^{-2} \cdot \mathrm{s}^{-1}\right)\end{array}$ & 21 & 14 & 14 & 30 & 21 & 20 \\
\hline $\begin{array}{l}\text { Light saturation point (LSP) } \\
\qquad\left(\mu \mathrm{mol} \cdot \mathrm{m}^{-2} \cdot \mathrm{s}^{-1}\right)\end{array}$ & 1000 & - & - & 1083 & 957 & 523 \\
\hline $\begin{array}{l}\text { Maximum net photosynthe } \\
\text { rate }\left(\mathrm{MP}_{\mathrm{n}}\right)\left(\mu \mathrm{mol} \mathrm{CO} \mathrm{CO}^{-2} \cdot \mathrm{s}^{-1}\right)\end{array}$ & 10.9 & - & - & 8.4 & 8.4 & 3.4 \\
\hline $\begin{array}{l}\text { Observed maximum PPFD } \\
\qquad\left(\mu \mathrm{mol} \cdot \mathrm{m}^{-2} \cdot \mathrm{s}^{-1}\right)\end{array}$ & 1349 & 1360 & 1280 & 1267 & 1162 & 976 \\
\hline $\begin{array}{l}\text { Observed air temperature } \\
\text { range }\left({ }^{\circ} \mathrm{C}\right)\end{array}$ & $6-26$ & $14-30$ & $21-32$ & $19-32$ & $9-30$ & $1-20$ \\
\hline $\begin{array}{c}\text { Air temperature at } L S P \\
\left({ }^{\circ} \mathrm{C}\right)\end{array}$ & 22 & - & - & 29 & 25 & 17 \\
\hline
\end{tabular}




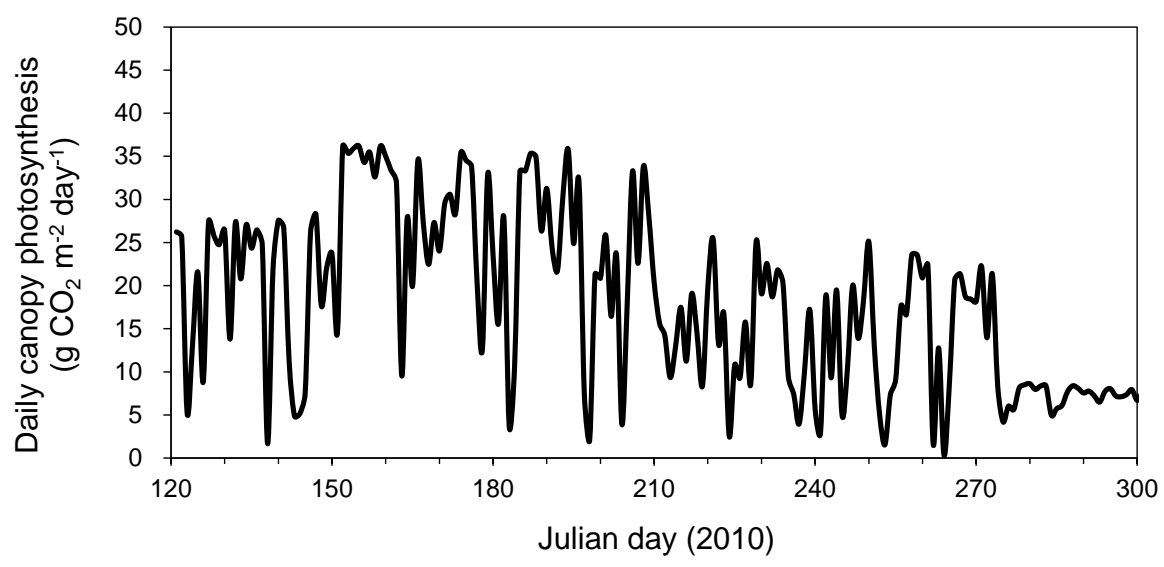

Figure 9. The seasonal variation of daily total canopy net photosynthesis rate $\left(\mathrm{g} \mathrm{CO}_{2} \mathrm{~m}^{-2}\right.$ day $^{-1}$ ) of $Q$. mongolica forest estimated at the Nam-San ecological-experimental site during the whole growing seasons from early May (beginning of the leaf unfolding) to late October (before the leaf shedding).

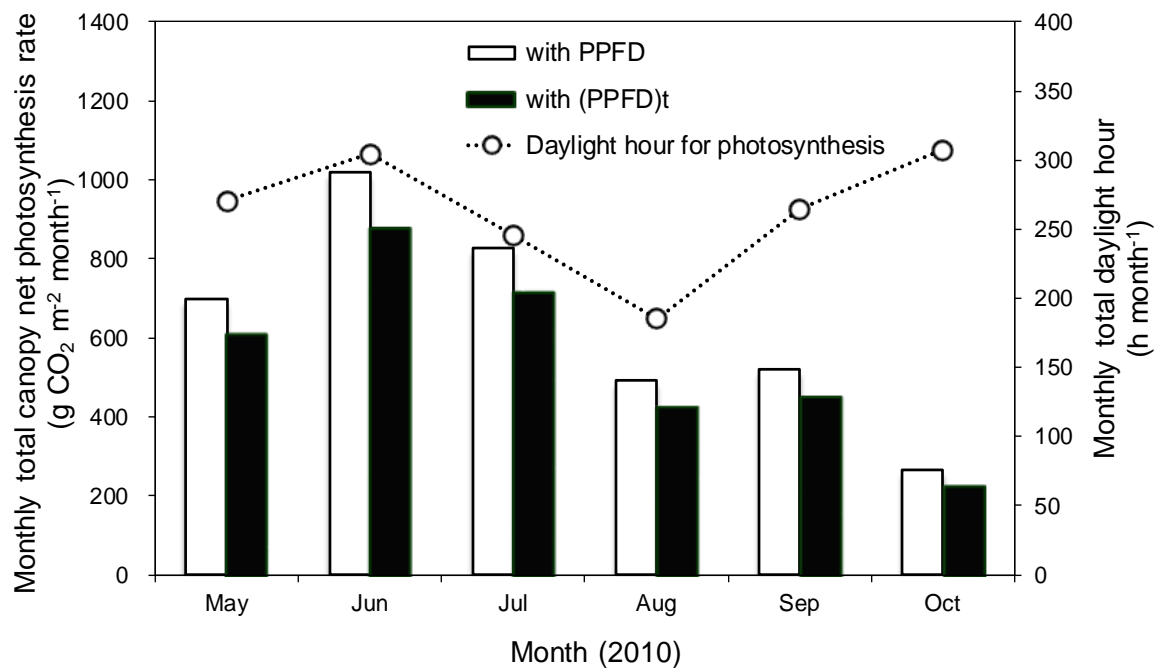

Figure 10. Comparison of the monthly total canopy net photosynthesis values estimated with PPFD ( $\square$; without change of solar elevation angle) and (PPFD) $)_{t}(\square$; with the solar elevation angle), and daylight hours (..O…) in the Q. mongolica forest stand during the whole growing season (May-October) in 2010.

maximum value is about $0.87 \mathrm{~kg} \mathrm{CO}_{2} \mathrm{~m}^{-2}$ month $^{-1}\left(1.02 \mathrm{~kg} \mathrm{CO}_{2} \mathrm{~m}^{-2} \mathrm{month}^{-1}\right)$ in June. However, in spite of the mid growing period of August, the canopy net photosynthesis rate is as low as $0.43 \mathrm{~kg} \mathrm{CO}_{2} \mathrm{~m}^{-2}$ month $^{-1}$ due to the cloudy weather in August and the monthly total daylight hour was about $60 \%$ of that in June (Figure 10). During the whole growing period (May to October) of 2010 at the site, the estimated total canopy net photosynthesis rate with (PPFD) ${ }_{t}(\mathrm{PPFD})$ is found to be about $3.3 \mathrm{~kg} \mathrm{CO}_{2} \mathrm{~m}^{-2}\left(3.9 \mathrm{~kg} \mathrm{CO}_{2} \mathrm{~m}^{-2}\right)$ that is within the range of 3.3 - $4.3 \mathrm{~kg} \mathrm{CO}_{2} \mathrm{~m}^{-2} \mathrm{yr}^{-1}$ for various cool-temperate deciduous forests estimated by Falge et al. [9] and Muraoka et al. [13].

In the whole growing season, the estimated total canopy net photosynthesis rate with (PPFD) ${ }_{t}$ is approximately $14 \%\left(0.6 \mathrm{~kg} \mathrm{CO}_{2} \mathrm{~m}^{-2}\right)$ lower than that estimated with PPFD, suggesting the total canopy net photosynthesis rate being sig- 
nificantly affected by the seasonal variations of the effective TPAI and the relative $(\mathrm{PPFD})_{t}$ within different canopy layers. This also suggests that the present method has a great potential for more accurate estimation of the photosynthesis rate in the forest stand.

\section{Conclusions}

Field measurements have been conducted throughout the growing season of the Q. mongolica forest at the Nam-San ecological experimental site in Seoul, Korea from May to October in 2010. An empirical model for the estimation of canopy net photosynthesis rate of $Q$. mongolica forest stand has been developed using the field experimental data by constructing the photosynthetic light response curve, vertical distributions of the leaf area index (LAI) and the photosynthetic photon flux density (PPFD) measured at around noon within the canopy of five levels $(0.5,9,12,14$ and $15 \mathrm{~m}$ heights).

It is found that LAIs within the canopy layers of the Q. mongolica forest stand show distinct seasonal variations with a maximum of $4.6 \mathrm{~m}^{2} \cdot \mathrm{m}^{-2}$ at the lowest canopy level ( $0.5 \mathrm{~m}$ above the ground) in July. The increasing rate of LAI is rather large during the leaf expansion period (late April to May) at all levels within the canopy compared to the decreasing rate during the leaf-litter fall period (late October to November). It is also found that the observed PPFD within the canopy can be properly regressed by the Beer-Lambert's law with the observed total plant area index (TPAI) within the canopy. The estimated light extinction coefficients $(\beta)$ are found to be a maximum value of $0.92-0.97$ in the early growing season (May) and the late growing season (October) with a near constant value of 0.57 - 0.59 during the peak growing season (June to August), suggesting a significant amount of PPFD being extinguished by the branch and stem (wood silhouette area index) during the early and late growing seasons.

The photosynthetic light response curve for the leaves of $Q$. mongolica is found to show a great increase of the net photosynthesis rate with the increase of PPFD in the peak growing seasons of June and July in 2010. However, in the early growing period of May and the late growing period of September the PPFD exceeding $1000 \mu \mathrm{mol} \cdot \mathrm{m}^{-2} \cdot \mathrm{s}^{-1}$ is founded to cause the decrease of the net photosynthesis rate due to the thermal stress probably caused by higher temperature than that at LSP which varies with the growth of the leaf.

The total canopy net photosynthesis rate for the growing period of $Q$. mongolica forest (May to October) at this site is found to be about $3.3 \mathrm{~kg} \mathrm{CO}_{2} \mathrm{~m}^{-2}$ that is about 1.3 times larger than the total soil respiration of $2.5 \mathrm{~kg} \mathrm{CO}_{2} \mathrm{~m}^{-2}$ measured at the same site for the same period [33]. The presently estimated canopy net photosynthesis rate is comparable to those estimated by Falge et al. [9] and Muraoka et al. [13], suggesting the potential usefulness of the present model for the estimation of the canopy net photosynthesis rate of $Q$. mongolica forest stand.

This study is mainly pertained to the estimation of the canopy net photosynthesis rate in the Q. mongolica forest stand with empirically derived the photo- 
synthetic light response curve using limited measurement data. Some important parameters affecting the net photosynthesis rate are not evaluated independently. This is now on hand at the Nam-San ecological-experimental site based on direct measurements of photosynthesis rates, respirations and environmental conditions continuously with the automatic chamber systems.

\section{Acknowledgements}

This work was funded by the Korea Meteorological Administration Research and Development Program under Grant KMIPA 2015-6040.

\section{References}

[1] Canadell, J.G., Mooney, H.A., Baldocchi, D.D., Berry, J.A., Ehleringer, J.R., Field, C.B., Gower, S.T., Hollinger, D.Y., Hunt, J.E., Jackson, R.B., Running, S.W., Shaver, G.R., Steffen, W., Trumbore, S.E., Valentini, R. and Bond, B.Y. (2000) Carbon Metabolism of the Terrestrial Biosphere: A Multi-Technique Approach for Improved Understanding. Ecosystems, 3, 115-130. https://doi.org/10.1007/s100210000014

[2] Cox, P.M., Betts, R.A., Jones, C.D., Spall, S.A. and Totterdell, I.J. (2000) Acceleration of Global Warming Due to Carbon-Cycle Feedbacks in a Coupled Climate Model. Nature, 408, 184-187. https://doi.org/10.1038/35041539

[3] Davidson, E.A., Janssens, I.A. and Luo, Y. (2006) On the Variability of Respiration in Terrestrial Ecosystems: Moving Beyond $\mathrm{Q}_{10}$. Global Change Biology, 12, 154-164. https://doi.org/10.1111/j.1365-2486.2005.01065.x

[4] Sitch, S., Smith, B., Prentice, I.C., Arneth, A., Bondeau, A., Cramer, W., Kaplan, J.O., Levis, S., Lucht, W., Sykes, M.T., Thonicke, K. and Venevsky, S. (2003) Evaluation of Ecosystem Dynamics, Plant Geography and Terrestrial Carbon Cycling in the LJP Dynamic Global Vegetation Model. Global Change Biology, 9, 161-185. https://doi.org/10.1046/j.1365-2486.2003.00569.x

[5] Sasai, T., Okamoto, K., Hiyama, T. and Yamagucchi, Y. (2007) Comparing Terrestrial Carbon Fluxes from the Scale of a Flux Tower to the Global Scale. Ecological Modelling, 208, 135-144. https://doi.org/10.1016/j.ecolmodel.2007.05.014

[6] Bondeau, A., Kicklighter, D.W., Kaduk, J. and The Participants of the Potsdam NPP Model Intercomparison (1999) Comparison Global Models of Terrestrial Net Primary Productivity (NPP): Importance of Vegetation Structure on Seasonal NPP Estimates. Global Change Biology, 5, 35-45. https://doi.org/10.1046/j.1365-2486.1999.00005.x

[7] Muraoka, H. and Koizumi, H. (2009) Satellite Ecology (SATECO)-Linking Ecology, Remote Sensing and Micrometeorology, from Plot to Regional Scale, for the Study of Ecosystem Structure and Function. Journal of Plant Research, 122, 3-20. https://doi.org/10.1007/s10265-008-0188-2

[8] Luo, Y., Hui, D., Cheng, W., Coleman, J.S., Johnson, D.W. and Sims, D.A. (2000) Canopy Quantum Yield in a Mesocosm Study. Agricultural and Forest Meteorology, 100, 35-48. https://doi.org/10.1016/S0168-1923(99)00085-4

[9] Falge, E., Baldocchi, D., Tenhunen, J., Aubinet, M., Bakwind, P., Berbigier, P., Bernhofer, C., Burba, G., Clement, R., Davis, K.J., Elbers, J.A., Goldstein, A.H., Grelle, A., Granier, A., Guðmundssonm, J., Hollinger, D., Kowalski, A.S., Katul, G., Law, B.E., Malhi, Y., Meyers, T., Monson, R.K., Munger, J.W., Oechel, W., Paw, U.K.T., Pilegaard, K., Rannik, Ü., Rebmann, C., Suyker, A., Valentini, R., Wilson, K. and Wofsy, S. (2002) Seasonality of Ecosystem Respiration and Gross Primary Production as Derived from FLUXNET Measurements. Agricultural and Forest Mete- 
orology, 113, 53-74. https://doi.org/10.1016/S0168-1923(02)00102-8

[10] Farquhar, G.D., von Caemmerer, S. and Berry, J.A. (1980) A Biochemical Model of Photosynthetic $\mathrm{CO}_{2}$ Assimilation in Leaves of $\mathrm{C}_{3}$ Species. Planta, 149, 78-90. https://doi.org/10.1007/BF00386231

[11] Wu, J., Guan, D., Sun, X., Zhang, M., Shi, T., Han, S. and Jin, C. (2006) Photosynthetic Characteristics of Dominant Tree Species and Canopy in the Broadleaved Korean Pine Forest of Changbai Mountains. Science in China. Series D, Earth Sciences, 49, 89-98. https://doi.org/10.1007/s11430-006-8089-5

[12] Arkebauer, T.J., Walter-Shea, E.A., Mesarch, M.A., Suyker, A.E. and Verma, S.B. (2009) Scaling up of $\mathrm{CO}_{2}$ Fluxes from Leaf to Canopy in Maize-Based Agroecosystems. Agricultural and Forest Meteorology, 149, 2110-2119. https://doi.org/10.1016/j.agrformet.2009.04.013

[13] Muraoka, H., Saigusa, N., Nasahara, K.N., Noda, H., Yoshino, J., Saitoh, T.M., Nagai, S., Murayama, S. and Koizumi, H. (2010) Effects of Seasonal and Interannual Variations in Leaf Photosynthesis and Canopy Leaf Area Index on Gross Primary Production of a Coo-Temperate Deciduous Broadleaf Forest in Takayama, Japan. Journal of Plant Research, 123, 563-576. https://doi.org/10.1007/s10265-009-0270-4

[14] Norman, J.M. (1993) Scaling Processes between Leaf and Canopy Levels. In: Ehlringer, J. and Field, C.B., Eds., Scaling Physiological Processes: Leaf to Global, Academic Press, London, 41-76. https://doi.org/10.1016/B978-0-12-233440-5.50010-5

[15] Ito, A., Saigusa, N., Murayama, S. and Yamamoto, S. (2005) Modeling of Gross and Net Carbon Dioxide Exchange over a Cool-Temperate Deciduous Broad-Leaved Forest in Japan: Analysis of Seasonal and Interannual Change. Agricultural and Forest Meteorology, 134, 122-134. https://doi.org/10.1016/j.agrformet.2005.11.002

[16] Ellsworth, D.S. and Reich, P.B. (1993) Canopy Structure and Vertical Patterns of Photosynthesis and Related Leaf Traits in Deciduous Forest. Oecologia, 96, 169-178. https://doi.org/10.1007/BF00317729

[17] Clark, D.B., Clark, A.C., Rich, P.M., Weiss, S. and Oberbauer, S.F. (1996) Landscape-Scale Evaluation of Understory Light and Canopy Structure: Methods and Application in a Neotropical Lowland Rain Forest. Canadian Journal of Forest Research, 26, 747-757. https://doi.org/10.1139/x26-084

[18] Rocha, A.V., Su, H.B., Vogel, C.S., Schmid, H.P. and Curtis, P.S. (2004) Photosynthetic and Water Use Efficiency Responses to Diffuse Radiation by an Aspen-Dominated Northern Hardwood Forest. Forest Science, 50, 793-801.

[19] Leuning, R., Kelliher, F.M., de Pury, D.G.G. and Schulze, E.D. (1995) Leaf Nitrogen, Photosynthesis, Conductance and Transpiration: Scaling from Leaves to Canopies. Plant, Cell \& Environment, 18, 1183-1200. https://doi.org/10.1111/j.1365-3040.1995.tb00628.x

[20] Koike, T., Kitao, M., Maruyama, Y., Mori, S. and Lei, T.T. (2001) Leaf Morphology and Photosynthetic Adjustments among Deciduous Broad-Leaved Trees within the Vertical Canopy Profile. Tree Physiology, 21, 951-958. https://doi.org/10.1093/treephys/21.12-13.951

[21] Sakai, T., Saigusa, N., Yamamoto, S. and Akiyama, T. (2005) Microsite Variation in Light Availability and Photosynthesis in a Cool-Temperate Deciduous Broadleaf Forest in Central Japan. Ecological Research, 20, 537-545. https://doi.org/10.1007/s11284-005-0067-4

[22] Wang, Y.P. and Jarvis, P.G. (1990) Description and Validation of an Array Model-MAESTRO. Agricultural and Forest Meteorology, 51, 257-280.

https://doi.org/10.1016/0168-1923(90)90112-J 
[23] Kimball, J.S., Thornton, P.E., White, M.A. and Running, S.W. (1997) Simulating Forest Productivity and Surface-Atmosphere Carbon Exchange in the BOREAS Study Region. Tree Physiology, 17, 589-599. https://doi.org/10.1093/treephys/17.8-9.589

[24] Lefsky, M.A., Cohen, W.B., Acker, S.A., Parker, G.G., Spies, T.A. and Harding, D. (1999) Lidar Remote Sensing of the Canopy Structure and Biophysical Properties of Douglas-Fir Western Hemlock Forests. Remote Sensing of Environment, 70, 339361. https://doi.org/10.1016/S0034-4257(99)00052-8

[25] Itano, S., Akiyama, T., Ishida, H., Okubo, T. and Watanabe, N. (2000) Spectral Characteristics of Aboveground Biomass, Plant Coverage, and Plant Height in Italian Ryegrass (Lolium multiiflorum L.) Meadows. Japanese Society of Grassland Science, $46,1-9$.

[26] Nasahara, K.N., Muraoka, H., Nagai, S. and Mikami, H. (2008) Vertical Integration of Leaf Area Index in a Japanese Deciduous Broad-Leaved Forest. Agricultural and Forest Meteorology, 148, 1136-1146. https://doi.org/10.1016/j.agrformet.2008.02.011

[27] Chazdon, R.L. and Pearcy, R.W. (1991) The Importance of Sunflecks for Forest Understory Plants. BioScience, 41, 760-766. https://doi.org/10.2307/1311725

[28] Bassow, S.L. and Bazzaz, F.A. (1998) How Environmental Conditions Affect Canopy Leaf-Level Photosynthesis in Four Deciduous Tree Species. Ecology, 79, 2660 2675. https://doi.org/10.1890/0012-9658(1998)079[2660:HECACL]2.0.CO;2

[29] Aber, J.D. and Melillo, J.M. (2001) Terrestrial Ecosystem. 2nd Edition, Academic Press, Cambridge.

[30] Ohtsuka, T., Mo, W., Satomura, T., Inatomi, M. and Koizumi, H. (2007) Biometric Based Carbon Flux Measurements and Net Ecosystem Production (NEP) in a Temperate Deciduous Broad-Leaved Forest Beneath a Flux Tower. Ecosystems, 10, 324 334. https://doi.org/10.1007/s10021-007-9017-z

[31] Kwak, Y.S. and Kim, J.H. (1992) Secular Changes of Density, Litterfall, Phytomass and Primary Productivity in Mongolian Oak (Quercus mongolica) Forest. The Korean Journal of Ecology, 15, 19-33.

[32] Kim, W.S., Cho, J.I., Myong, G.M., Mano, M., Komori, D. and Kim, S.D. (2008) Quality Assessment of Data from the Daegwallyeong Flux Measurement Station (DFMS) Based on Short-Term Experiments. Journal of Agricultural Meteorology, 64, 111-120. https://doi.org/10.2480/agrmet.64.3.3

[33] Joo, S.J., Park, S.U., Park, M.S. and Lee, C.S. (2012) Estimation of Soil Respiration Using Automated Chamber Systems in an Oak (Quercus mongolica) Forest at the Nam-San Site in Seoul, Korea. Science of the Total Environment, 416, 400-409. https://doi.org/10.1016/j.scitotenv.2011.11.025

[34] Norman, J.M. and Campbell, G.S. (1989) Canopy Structure. In: Pearcy, R.W., Ehlringer, J., Mooney, H.A. and Eundel, P.W., Eds., Plant Physiological Ecology. Field Methods and Instrumentation, Chapman and Hall, London and New York, 301325. https://doi.org/10.1007/978-94-009-2221-1_14

[35] Welles, J.M. and Norman, J.M. (1991) Instrument for Indirect Measurement of Canopy Architecture. Agronomy Journal, 83, 818-825. https://doi.org/10.2134/agronj1991.00021962008300050009x

[36] Kucharik, C.J., Norman, J.M. and Gower, S.T. (1998) Measurement of Branch Area and Adjusting Leaf Area Index Indirect Measurements. Agricultural and Forest Meteorology, 91, 69-88. https://doi.org/10.1016/S0168-1923(98)00064-1

[37] Monsi, M. and Saeki, T. (1953) Über den Lichtfaktor in den Pflanzengesellschaften und seine Bedeutung für die Stoffproduktion. Japanese Journal of Botany, 14, 22-52. 
(In German)

[38] Monsi, M. and Saeki, T. (2005) On the Factor Light in Plant Communities and Its Importance for Matter Production. Annals of Botany, 95, 549-567.

https://doi.org/10.1093/aob/mci052

[39] Suwa, R., Khan, M.N.I. and Hagihara, A. (2006) Canopy Photosynthesis, Canopy Respiration and Surplus Production in a Subtropical Mangrove Kandelia candel forest, Okinawa Island, Japan. Marine Ecology Progress Series, 320, 131-139. https://doi.org/10.3354/meps320131

[40] Koyama, K. and Kikuzawa, K. (2011) Reduction of Photosynthesis before Midday Depression Occurred: Leaf Photosynthesis of Fagus crenata in a Temperate Forest in Relation to Canopy Position and a Number of Days after Rainfall. Ecological Research, 26, 999-1006. https://doi.org/10.1007/s11284-011-0859-7

[41] Noilhan, J. and Planton, S. (1989) A Simple Parameterization of Land Surface Processes for Meteorological Models. Monthly Weather Review, 117, 536-549. https://doi.org/10.1175/1520-0493(1989)117<0536:ASPOLS>2.0.CO;2

Submit or recommend next manuscript to SCIRP and we will provide best service for you:

Accepting pre-submission inquiries through Email, Facebook, LinkedIn, Twitter, etc. A wide selection of journals (inclusive of 9 subjects, more than 200 journals)

Providing 24-hour high-quality service

User-friendly online submission system

Fair and swift peer-review system

Efficient typesetting and proofreading procedure

Display of the result of downloads and visits, as well as the number of cited articles

Maximum dissemination of your research work

Submit your manuscript at: http://papersubmission.scirp.org/

Or contact ajps@scirp.org 